\title{
Crossing Boundaries: VET, the Labour Market and Social Justice
}

\author{
James Avis* \\ HudCRES (Huddersfield Centre for Research in Education and Society), University of \\ Huddersfield, Queensgate, Huddersfield HD1 3DH, Great Britain
}

Received: 11.04.2018; Accepted: 01.06.2018; Published: 22.11.2018

\begin{abstract}
Purpose: The paper explores the relationship between vocational education and training (VET), the labour market and social justice in the current conjuncture.

Approach: The paper adopts an approach rooted in critical policy analysis. It consequently sets the discussion within the wider socio-economic and political context. Such an approach enables an exploration of the changing nature of waged labour in current conditions.

Results: A critical policy analysis facilitates a discussion of the labour process, waged labour and its intensification. At the same time these processes are allied to the effective expulsion and marginalisation of particular groups of workers from employment. Importantly, such processes need to be placed in their localised and spatial context within particular social formations.

Conclusion: Equity models of social justice that emphasise equal opportunities, are restrictive and can be contrasted with equality models which have a more expansive and philosophically rooted understanding of justice. The paper through its examination of the salience of VET in the current conjuncture as well as its significance for a post austerity democratic and radical politics, argues for a relational analysis that seeks to interrupt the patterns of inequality precipitated by neo-liberalism.
\end{abstract}

Keywords: VET, Vocational Education and Training, Neo-Liberalism, Labour Market, Surplus Labour Curriculum Development

\footnotetext{
${ }^{*}$ Corresponding author: j.avis@hud.ac.uk
}

ISSN: 2197-8646

http://www.ijrvet.net 


\section{VET, the Labour Market and Social Justice}

This paper raises a number of questions concerned with vocational education and training (VET) and its relationship to social justice. It commences by unpacking the notion of VET and then addresses the relationship between VET and the labour market. It considers post-capitalism in relation to debates concerned with jobless growth and surplus labour. Neo-liberalism, the politics of austerity and capitalism serve as a backdrop to the paper. It is important to acknowledge that processes that occur within a particular social formation cannot be thought of outside global, regional, national and indeed, local relations. Such boundaries are both fluid and permeable, being interrelated and are potentially in flux.

I would like to start with two of my favourite quotes both of which raise questions about the way in which think about VET, the labour market and social justice. The first is from Allman, McLaren, and Rikowski, and the second from the English Commission on Adult Vocational Teaching and Learning.

Education plays a key role in the perpetuation of the capital relation; this is the skeleton in capitalist education's dank basement. It is just one of the many reasons why, in contemporary capitalist society, education [and we might add VET] assumes a grotesque and perverted form. It links the chains that bind our souls to capital (Allman et al., 2003, p. 149-150).

This quote is salutary and reminds us of the relationship between education the wider economy, offering a corrective to those accounts that too readily associates VET with social justice (Wheelahan, 2016).

The second quote is from the Commission on Adult Vocational Teaching and Learning (2013, p. 5).

The best vocational teaching and learning combines theoretical knowledge from the underpinning disciplines (for example, maths, psychology, human sciences, economics) with the occupational knowledge of practice (for example, how to cut hair, build circuit boards, administer medicines). To do this, teachers, trainers and learners have to recontextualise theoretical and occupational knowledge to suit specific situations. Both types of knowledge are highly dynamic. So individuals need to carry on learning through being exposed to new forms of knowledge and practice in order to make real the line of sight to work (Commission on Adult Vocational Teaching and Learning).

Whilst superficially the Commission's position appears progressive it reflects a somewhat restrictive model of VET, being preoccupied with a clear line of sight to work. Such an orientation can very easily lead to a narrow focus on the needs of employers. To the extent that creativity and innovation is encouraged and valued this is on the basis that it contributes to successful workplace practices. Critique is encouraged provided it rests 
within this terrain and is 'business facing', having a clear line of sight to work - that is to say, waged labour.

Much the same critique could be applied to models of competency, whilst recognising that this much like VET, is a contested and chameleon like term.

'Competence' is the capability of a person (or an organisation) to reach specific achievements. Personal competencies comprise integrated performanceoriented capabilities, which consist of clusters of knowledge structures and also cognitive, interactive, affective and where necessary psychomotor capabilities and attitudes and values, which are required for carrying out tasks, solving problems and more generally, effectively functioning in a certain profession, organisation, position or 'role' (Biemans et al., 2009, p. 267-268).

This echoes Fuller and Unwin's discussion of expansive and restrictive learning environments in which some workplaces have cultures that facilitate expansive learning cultures whilst others are more restrictive (Evans et al., 2006, p. 61, Figure 3.2).

There is also an affinity with Winch's discussion of the German notion of 'Kompetenzen', which suggests a broader understanding of competence than that found in Anglo-Saxon societies. For Winch:

[Kompetenzen] is more than a bundle of skills, but is unified through a conception of agency which involves planning, control, co-ordination, selfmonitoring and evaluation, as well as the performance of a variety of tasks requiring specific skills. It also includes the ability to appreciate the broader economic and civic implications of occupational action (Winch, 2012, p. 179).

There are two points to be made. Firstly, "the ability to appreciate the broader economic and civic implications of occupational action" goes beyond Anglo-Saxon, restrictive and narrow definitions of competence and importantly, serves as a critical resource. At the same time, it readily lies within a specific socio-economic context that accepts capitalist relations. At best this resonates with social democracy, or more precisely in the German case, with Christian Democrat versions of Corporativism - or what Bosch and Kalina (2016) refer to as the Bismarckian welfare state.

Secondly, Thelen and Busemeyer $(2008 ; 2011)$ point to what they refer to as the shift from collectivism to segmentalism in German VET.

In collectivism employers were encouraged to over train thereby producing workers with broad and portable occupational skills whereas in the latter training is organised around internal labour markets and the specific needs of the companies concerned (Thelen \& Busemeyer, 2011, p. 69).

However, it is important to recognise that such relations are not fixed but are on-goingly reconstructed and negotiated. The point is VET is always set within socio-economic and historical conditions, with the shift from collectivism to segmentalism reflecting a change in the balance of power between labour and capital. This also aligns with the 
competitive strategy of particular firms who respond to the broader context in which they are placed, the particular institutional complementarities (Kenworthy, 2004) as well as the specificity of the accompanying institutional and partisan politics (Busemeyer, 2015; Thelen, 2014).

We could think about the way in which social democracy has been undermined by neoliberalism. Sweden would be a case in point and illustrates the impact of neo-liberalism upon a specific social formation and the way in which social democratic concessions have been eroded. Much the same questions could be raised about German corporativism. Harvey (2014, p. 158-159) amongst others have commented on wage repression in Germany in the early years of the $21^{\text {st }}$ century. In 2008 Solow commented on the significance of low waged work in Germany, with the International Federation of Red Cross and Red Crescent Societies (IFRC) commenting

Even in Germany, almost 600,000 working people had to ask for additional benefits to pay their bills in August 2012 (International Federation of Red Cross and Red Crescent Societies, 2013, p. 20).

Relatedly, Brown, Lauder and Ashton (2011) have commented on the importance of international flows of labour in the skill strategies of organisations which reduce training costs. Such processes are allied to the hollowing out of the class structure, a shrinking middle class, the significance of mini-jobs, the encroachment of work upon our lives related to the intensification of labour and increased levels of exploitation and precariousness. These processes have to be set within German neo-mercantilism's concern with an export led growth regime and its particular relation to the management of the Euro so as to secure competitive advantage (Jessop, 2015, p. 17-18). In addition, Thelen (2014, p. 13-14) touches on both the importance of flexibilisation as well dualization, whereby core workers are covered by collective agreements alongside an unorganised and unregulated periphery. It is important to acknowledge that VET through its very construction and accompanying social relations lurches towards a form of labourism. In 1983 Ralph Miliband, described this as "an ideology of social reform, within the framework of capitalism, with no serious ambition of transcending that framework" (p. 293).

Notwithstanding its contradictions, the point I am trying to make is that VET is a contested terrain and whilst within specific constructions progressive possibilities reside these are dependent on the particular context in which they are placed. For example, expansive version of VET that embraces notions of citizenship, democracy and individual development are conditional upon the balance of power between labour and capital present within the social formation, and indeed beyond (Fuller \& Unwin, 2003). In the latter case it is important to acknowledge the global context in which this may occur, one in which certain social formations and groups of workers are privileged over others.

\section{Neo-Liberalism, Regional Inequalities and Globalisation}

Here I address the relationship between VET, the labour market and social justice. The starting point is with the UK and in particular, England as a case in point. This is a 
social formation marked by under- and unemployment and a labour force that is both over educated and over qualified. Within this society, there has been a hollowing out of the middle class and an increasing polarisation of income and wealth allied to increased precariousness of employment. The current fear is that these features will be exacerbated by globalisation and the consequences of Brexit.

There was a time when experts argued the English labour force was under-skilled and in need of up-skilling. Currently the rhetoric is that people have developed the wrong skills which is reflected in the notion of a skills gap. This debate is not restricted to England but has a wider purchase in relation to the way in which we think about the labour market and social justice. The above characteristics could be seen as a feature of liberal labour markets or as Esping-Andersen suggests, a liberal welfare regime. Notably Esping-Andersen (1990) suggests there are three broad versions of welfare regimes, the liberal, the social democratic and the corporatist, with these being set within very particular pattern of institutional and societal arrangements.

Esping-Anderson associates the Anglo-Saxon societies to the liberal welfare regime. However, it is important to acknowledge that in the years immediately following the end of the second world war, it would not have been too fanciful to describe an English social democratic welfare regime or settlement (Education Group, 1981). This settlement was interrupted by Thatcherism and the ascendancy of the New Right. Rather than regime I prefer the notion of settlement. The point being that settlements are not only negotiated but have to be constantly re-secured. They are therefore always vulnerable and in danger of unravelling. Notably, in relation to Thatcherism, the New Right and neo-liberalism, this settlement has never been fully secured and is on-goingly contested (Johnson, 1998), though there has been an attempt to render it hegemonic and embed it in common sense.

Neo-liberal concerns have impacted upon Germany and continental Europe in relation to competitiveness, the market, and austerity. IFRC notes the salience of mini jobs, low waged work in Germany, with Streeck commenting on the significance of cuts in welfare and the decline of the middle class, which articulates with the consolidation state. Streeck (2014) has discussed the shift from a tax state to that of a debt or consolidation state in which the aim is to service debt whilst maintaining competitiveness.

Consolidation as a confidence-building measure proceeds, almost as a matter of course, not by raising revenue but by cutting expenditure... A budget surplus is preferably used to pay off debt or cut taxes, to suppress political temptations to restore previous spending cuts (my emphasis) (Streeck, 2016, p. 122-3).

It is important to acknowledge that capital is not all of a piece and that the above processes will be played out differentially in relation to the specificity of the particular social formation and labour market. Jessop (2015) for example draws our attention to the differences present within neoliberal capitalism - his variegated neoliberalism referring to the distinction between the finance dominated versions found in the US/UK as against German neo-mercantilism.

One of the successes of neo-liberalism has been to break down national borders whilst simultaneously emphasising the importance of regionalism and localism. On a simplistic 
level this can be seen in England in the division between north and south, with the former having higher rates of disadvantage in terms of unemployment and restricted labour markets. Paradoxically, and despite the rhetoric, such regional disparities are also found in continental Europe, East and West Germany being a case in point.

Social geographers (Martin \& Morrison, 2003) draw our attention to the spatial and constructed nature of labour markets as well as their porosity. Alongside a local labour market that features low waged intermittent work, or indeed no work at all of the type that Shildrick et al. (2012) discuss in the north of England, there may be other workers lodged within a global labour market of high skilled/waged work. Such global and local labour markets may in some senses overlap but will also be on-goingly constructed and subject to change (Martin \& Morrison, 2003). This means that within a social formation, areas of full employment and putative skills gaps/mismatch sit alongside regions/localities characterised by multiple disadvantage and the lack of decent jobs (Keep \& James, 2012; Orr, 2016).

\section{Digitalisation, Jobless Growth and Unhelpfully Reforms}

It has been argued that globalisation in the 1970s was linked to de-industrialisation which led to low waged manufacturing processes being relocated in the emerging economies. This impacted most heavily upon US and UK's manufacturing sectors. It is also allied to changes in technology and the accompanying changes to labour processes. This can be seen both in the spectre of 'jobless growth' as well as the way in which the internet can effectively lead to a 24 hour labour process that follows time zones and reflects the compression of time and space.

This has consequences for the global labour market with respect to particular skills and can be seen in the manner in which design processes can be distributed across the globe resulting in a high skill/low wage nexus (Brown, Lauder, \& Ashton, 2011). In addition, Brown et al. (2011) draw our attention to digital Taylorism, that is to say the use of digital technologies to deskill and standardise formerly skilled jobs of knowledge workers. This has particularly impacted upon white collar and professional occupations (Susskind \& Susskind, 2015; and see Autor \& Dorn, 2013). This represents, in part, the hollowing out of middle level jobs but also moves in the direction of 'technological unemployment' with digitised jobs leading to a loss of employment (Peters, 2016).

In some of the arguments that stress technological unemployment there is an element of determinism whereby digitalisation and the increasing use of algorithms carries with it the inevitability of job losses. Frey and Osborne write, citing a technical report produced by McKinsey Global Institute (MGI),

Estimates by MGI (2013) suggests that sophisticated algorithms could substitute for approximately 140 million full-time knowledge workers worldwide... The trend is clear: computers increasingly challenge human labour in a wide range of cognitive tasks (2013, p. 19).

Not dissimilar arguments are a feature of recent research addressing robotisation (Ford, 2016), the fourth industrial revolution, or what some term the second industrial age 
(Brynjolfsson \& McAfee, 2011; 2014) together with those that discuss 'job polarisation' (Heyman, 2016). There are several points to be made. Firstly, Pfeiffer (2017) argues that much of this debate is overstated and fails to have a sufficient empirical base or engagement with manufacturing labour in highly automated and digitalised work environments. She emphasises the needs for skilled labour in such contexts, a not dissimilar argument is made by Saniter and Howe (2017). At the same time, such processes have an impact on the graduate labour market. Commenting on over-education/qualification in the UK, Green, Felstead, Gallie, \& Henseke (2016, p. 128) suggest,

The number of graduates in the labour force has begun, especially in recent years, to outpace the number of graduate jobs. This is why, increasingly, some graduates are finding themselves in lower-ranking jobs. . . by the middle of the 2000s it became evident that there was an increasing dispersion in the graduate pay premium.

The dispersion of this pay premium is related to the subject studied, the university attended, the individual's race and gender as well as their class origin (DBIS, 2016; Reay, David, \& Ball, 2005).

Unsurprisingly, labour market analyses are predicated upon waged labour and therefore underestimate the significance of unwaged work. For example, user activity on the Internet can be construed as a source of 'free' unwaged labour as it may contribute towards the profits of capital, as can the development of open source software (see Avis \& Reynolds, 2017; Frayssé, 2015). Standing (2014) also reminds us of the unwaged work of the unemployed searching for paid labour.

In addition, it is important to acknowledge forms of labour that are unwaged but which are in many senses 'productive' in as much as they produce value for participants and contribute to wellbeing. The domestic labour of women would be a case in point as would other activities in the wider community - volunteering, visiting neighbours, caring for the environment and so on. The important point is that there is an infinite potential for 'productive' labour - what could be described as 'really useful labour' in a capitalist and post-capitalist society.

Rustin (2013) for example, calls for a different economic and institutional architecture that would prioritise the cultivation of human needs and capacities and necessitates the re-evaluation of the way in which we understand economic relations and growth. This argument faces in several directions at once. It could align itself with Marxist conceptualisations of 'species being' and 'unalienated' labour. Alternatively, it could sit alongside an inclusive capitalism predicated on a model of 'workfare' with all the difficulties this portends. The danger is that leftist strategies can easily fold over into a form of capitalist reformism rather than one committed to revolutionary reformism predicated on an anti-capitalist stance.

To engage in 'really useful labour' necessitate the financial resources that would facilitate access to these opportunities. The difficulty is that most lack the resources, or where they do exist, these are in the form of workfare. To address this issue requires a fundamental rethinking of the nature of waged work, demands the provision of a univer- 
sal basic income (Standing, 2014), and a revolutionary desire to struggle towards for a post-capitalist society.

Although it is correct to argue that over-qualification and underemployment are features of many western labour markets, it is incorrect to imply that there are insufficient opportunities, the need for graduate level labour, or indeed any type of 'productive' work. In this instance 'productive' work is synonymous with 'really useful labour'. This type of analysis demands that we address the distinction between waged work/labour and unwaged work/labour and their validation. With respect to waged labour, whilst many on the left condemn exploitative and oppressive labour, they nevertheless come near to celebrating such work in its absence (Avis, 2014).

Exclusion from waged labour is seen to carry a raft of negative social consequences deemed harmful for both the individual and society (see for example, Wilkinson \& Pickett, 2010). A rather different emphasis that draws on 'really useful labour' resonates with Marx's imaginary of 'unalienated' labour. For Marx labour is central to our 'species being'. Italian workerism, cognitive capitalism and antiwork (Weeks, 2011) offer a rather different view of waged labour. These analyses question the productivist and economistic assumptions that underpin much of the debate and are particularly salient in the current conjuncture facing western economies. Blacker suggests,

The current neoliberal mutation of capitalism has evolved beyond the days when the wholesale exploitation of labor under-wrote the world system's expansion. While "normal" business profits plummet and theft-by-financerises, capitalism now shifts into a mode of elimination that targets most of us - along with our environment - as waste products awaiting managed disposal (Blacker, 2013, p. 1) (and see Marsh, 2011).

Those neo-liberal processes that have hollowed out middle level occupational positions and exacerbated the development of a polarised labour market and income distribution have created a socio-economic context in which the winner-takes-all, referred to by Piketty as 'meritocratic extremism' (2014, p. 416).

Such a context questions the myth of meritocracy. Many of those who are located at the margins of the class structure, will materially experience the collapse of the opportunity structure (Brown, 2013). The result is that aspirations for mobility will be stalled, or the aim may be to avoid downward mobility in what is experienced as an increasingly precarious and insecure situation. Roberts (2016) has drawn our attention to similar conditions facing East German youth and suggests this anticipates all our futures in the west rather than being a glitch in the modernisation of the former GDR.

There is a reformism here that calls for a politics of access and a fairer distribution of life chances set within a flatter distribution of income and wealth. This can easily fold over into a social democratic concern with equal opportunities, a stance that stops short of a revolutionary and anti-capitalist project. This is what Lingard, Sellar and Savage (2014) refer to as an equity model of social mobility, predicated upon individualism and the development of human capital which reduces social mobility to a technical issue. At best such a version has an affinity with a social democracy that seeks to soften 
structural inequality without posing a significant challenge to patterns of inequality that are grounded in capitalist relations. Notably, the struggle between labour and capital may result in an apparently more egalitarian social formation as it did following the end of the Second World War when the balance of power between labour and capital shifted in favour of the former. However, such gains have been reversed, or at least stalled in the current conjuncture in an increasingly polarised social formation in which the antagonistic relations between labour and capital have shifted in favour of the latter. Whilst such processes are most acutely felt in Anglophone societies, they are also present to a lesser extent in continental Europe.

As against an equity model of social mobility an equality model is predicated on a much broader, philosophically and politically informed understanding that goes beyond technicism and individualism and offers a challenge not only to neo-liberalism but presage post-capitalism. A hollowed out and polarised class structure offers limited upward mobility. An equity model can only serve to justify and entrench inequality under the illusion of meritocracy.

Byrne (2017) in a critique of Wilkinson and Pickett's The Spirit Level, (2010) sets this within a Fabian and technicised discussion of inequality that seeks to minimise the inequities of capitalism but nevertheless leaves these relations in place. In this sense social democracy represents an ideology that celebrates a move towards a more egalitarian social structure whilst simultaneously attempting to secure the interests of capital.

The limits of this reformist politics set in the current context in which class structure is being hollowed out, could prefigure a rather different class politics. Byrne (2017) in a paper which references the past as well as the present seeks to resuscitate the notion of the aristocracy of labour.

He uses this term to refer to those in the top half but outside the 'top decile and certainly the top 1 per cent' (111) of the income distribution. This group depends on its income from waged labour but has experienced a decline in real wages, facing growing insecurity and whose children face an uncertain future. Brown (2016) in a rather different vein refers to 'a crisis in middle class reproduction that has yet to find expression in class opposition' (p. 205).

Byrne's analysis suggests a common cause across the gradients of class structure amongst those who have to sell their labour in order to survive. Perhaps the specificity of the current socio-economic context prefigures this possibility. The alternative is a politics that continually shuffles class positions in a hierarchy, for as Brown reminds us 'positional conflict and inequalities in power are defining features of the competition for livelihood within capitalist societies' (2016, p. 202).

Such a stance poses questions about the way in which we conceive capitalism and the possibilities for its reform/transformation. The issue is whether we conceive neoliberalism as a distinctive form or merely an expression of the logic of the system that is driven by the pursuit of capital accumulation.

In the latter case the particular variety of capitalism is the outcome of the struggle between capital and labour and the subsequent balance of power. This means that in those forms akin to social democracy there is a constant struggle by capital to reassert its 
power, and under neo-liberalism by labour to constrain the power of capital. This toing and froing fails to resolve such tendencies and can only be addressed in a post-capitalist society forged through struggle.

\section{Towards a Conclusion}

In this paper I have explored the relationship between VET, the labour market and social justice, by placing the discussion in the wider socio-economic and political context and the changing nature of waged labour. This sits alongside not only the intensification of labour but also the expulsion and marginalisation of particular groups of workers from employment - the notion of surplus labour. This is particularly salient in relation to questions of social justice, leading to restricted opportunities for social mobility and thus the entrenchment of inequality. Importantly, such processes need to be placed in their spatial and global context within particular social formations - if you like the pattern of social relations. So for example one cannot make sense of Germany's position without considering local, regional, national and global relations, acknowledging these are framed by neo-liberalism. I guess the key question is whether capitalism is all of a piece, or whether some form of reinvigorated egalitarian capitalism promises social justice. A possibility which I doubt.

\section{References}

Allman, P., McLaren, P., \& Rikowski, G. (2003). "After the Box People." In J. FreemanMoir and A. Scott, (eds) Yesterday's Dreams: International and Critical Perspectives on Education and Social Class, Canterbury NZ, Canterbury University Press.

Avis, J. (2014). Austerity and modernisation, One Nation Labour - Localism, the Economy and Vocational Education and Training in England Journal for Critical Education Policy Studies, 12:2, 225-254.

Avis, J. (2018). The re-composition of class relations: Neo-liberalism, precariousness, youth and education, in J. Smyth, R. Simmons (eds) Education and Working Class Youth, London, Palgrave (in press).

Avis, J., \& Reynolds, C. (2017). The digitalisation of work and social justice - reflections on the labour process of English Further Education (VET) teachers, Harteis, C. (ed) The impact of digitization in the workplace: An educational view Dordrecht, Springer series Professional and Practice-based Learning.

Autor, D., \& Dorn, D. (2013). The Growth of Low-Skill Service Jobs and the Polarization of the US Labor Market, The American Economic Review,103(5), 1553-1597.

Blacker, D. (2013). The falling rate of learning and the neoliberal endgame, London, Zero books.

Bosch, G., \& Kalina, T. (2016). The Erosion of the German middle class, in D. VaughanWhitehead (ed) Europe's Disappearing middle class, Cheltenham, Edward Elgar, 198-243. 
Brown, P. (2013). Education, opportunity and the prospects for social mobility. British Journal of Sociology of Education, 34(5-6), 678-700.

Brown, P. (2016). Higher education, credential competition, and the graduate labour market, in A. Furlong, J. E. Cote (eds). Routledge handbook of the sociology of higher education, London, Routledge, 197-207.

Brown, P., Lauder, H., \& Ashton, D. (2011). The Global Auction. Oxford: Oxford University Press.

Brynjolfsson, E., \& McAfee, A. (2011). Race against the machine: How the digital revolution is accelerating innovation, driving productivity, and irreversibly transforming employment and the economy. Lexington, MA, Digital Frontier Press.

Brynjolfsson, E., \& McAfee, A. (2014). The Second Machine Age: Work, Progress and Prosperity in a Time of Brilliant Technologies. New York, Norton \& Company.

Byrne, D. (2017) Beyond mere equality - a politics of class analysis not 'evidence', in Soundings, issue 4, 105-116.

Commission on Adult Vocational Teaching and Learning (CAVTL). (2013). It's About Work... Excellent Adult Vocational Teaching and Learning: The Summary Report of the Commission on Adult Vocational Teaching and Learning.

Department for Business Innovation and Skills (DBIS). (2016). Graduate Labour market Statistics, London, Crown copyright.

Education Group. (1981). Unpopular Education Schooling and social democracy in England since 1944 London, Hutchinson.

Esping-Andersen, G. (1990). The three worlds of welfare capitalism, Cambridge, Polity.

Ford, M. (2016). The rise of the robots, London, Oneworld.

Frayssé, O. (2015). Is the concept of rent relevant to a discussion of surplus-value in the digital world, in E. Fisher, C. Fuchs (eds). Reconsidering Value and Labour in the Digital Age, Basingstoke, Palgrave MacMillan, 172-187.

Frey, C. B., \& Osborne, M., A. (2013). The Future of Employment: How Susceptible are Jobs to Computerisation? Oxford Martin School, University of Oxford.

Fuller, A., \& Unwin, L. (2003). Learning as apprentices in the contemporary UK workplace: Creating and managing expansive and restrictive participation. Journal of Education and Work, 16(4), 407-26.

Green, F., Felstead, A., Gallie, D., \& Henseke, G. (2016). Skills and work organisation in Britain: A quarter century of change, Journal of Labour Market Research 49, p. 121-132, doi:10.1007/s12651-016-0197-x

International Federation of Red Cross and Red Crescent Societies. (2013). Think differently Humanitarian impacts of the economic crisis in Europe, IFRC Geneva.

Harvey, D. (2014). Seventeen Contradictions and the end of capitalism, London, Profile books.

Jessop, B. (2015). Neoliberalism, finance-dominated accumulation and enduring austerity: a cultural political economy perspective, in K. Farnsworth, Z. Irving (Eds). Social Policy in times of Austerity, Bristol, Policy Press.

Johnson, R. (1998). Sexual emergenc(i)es: Cultural theories and contemporary sexual politics. Keywords, 1, 74-94. 
Keep, E., \& James, S. (2012). A Bermuda Triangle of Policy? 'Bad Jobs', Skills Policy and Incentives to Learn at the Bottom End of the Labour Market, Journal of Education Policy, 27(2), 211-230.

Kenworthy, L. (2004). Egalitarian Capitalism, New York, Russell Sage Foundation.

Lingard, B., Sellar, S., \& Savage, G. (2014). "Re-Articulating Social Justice as Equity in Schooling Policy: The Effects of Testing and Data Infrastructures." British Journal of Sociology of Education 35(5), 710-730.

Marsh, J. (2011). Class Dismissed, Month Review Press.

Martin, R., \& Morrison, P. S. (2003). The geographies of labour market inequality, in R. Martin, P. S. Morrison (Eds). Geographies of Labour Market inequality, London, Routledge.

MGI. (2013). Disruptive technologies: Advances that will transform life, business, and the global economy. Tech. Rep., McKinsey Global Institute.

Miliband, R. (1983). Class Power and State Power, London, Verso.

Orr, K. (2016). "Who cares about vocational education and training? Pedagogy and pathways for the "overlooked middle" inaugural lecture, The University of Huddersfield, $1^{\text {st }}$ December.

Peters, M. A. (2016). Technological unemployment: Education for the fourth Industrial Revolution, Educational, Philosophy and Theory, doi:10.1080/00 131857.2016.1177412

Pfeiffer, S. (2017). Work 4.0 - new challenges for participation and qualification, In: F. Kaiser, S. Krugmann (Eds). Social dimensions and participation in Vocational Education, University of Rostock, Rostock 25-29.

Piketty, T. (2014). Capital in the Twenty-First Century. Cambridge MA: Belknap.

Reay, D., David, M., \& Ball, S. J. (2005). Degrees of Choice: social class, race and gender in higher education. Stoke on Trent: Trentham Books.

Resolution Foundation. (2016). Zero-hours contract workers face a 'precarious pay penalty' of 1,000 a year, http://www.resolutionfoundation.org/media/press-releases/zero hours-contract-workers-face-a-precarious-pay-penalty-of-1000-a-year/accessed 30 Dec 2016.

Roberts, K. (2016). Youth cultures and the formation of a new political generation in Eastern Europe, In: M. Schwartz, H. Winkel (Eds). Eastern European Youth Cultures in a Global Context, London, Palgrave, 46-63.

Rustin, M. (2013). A relational society, In: S. Hall, D. Massey, M. Rustin, (Eds). After neoliberalism? The Kilburn manifesto http://lwbooks.co.uk/journals/soundings/pdfs /Soundings\%20Manifesto_Rustin.pdf accessed 7 August 2013.

Saniter, A., \& Howe, F. (2017). Industry 4.0 - what's behind the mask? A case of addititve manufacturing, In: F. Kaiser, S. Krugmann (Eds). Social dimensions and participation in Vocational Education, University of Rostock, Rostock 172-176.

Shildrick, T., MacDonald, R., Webster, C., \& Garthwaite, K. (2012). Poverty and Insecurity: Life in low-pay, No-pay Britain, Bristol, Policy Press.

Solow, R. (2008). The German story, In: G. Bosch, C. Weinkopf (Eds) Low-wage work in Germany, New York, The Russell Sage foundation, 1-14.

Standing, G. (2014). A precariat charter, London, Bloomsbury. 
Streeck, W. (2014). Buying time: the delayed crisis of democratic capitalism, London, Verso.

Streeck, W. (2016). How will capitalism end, London, Verso.

Susskind, R., \& Susskind, D. (2015). The future of the professions, Oxford, Oxford University Press.

Thelen, K. (20O4). How institutions evolve, Cambridge, Cambridge University Press.

Thelen, K. (2014). Varieties of liberalization and the new politics of social solidarity, New York, Cambridge University Press.

Thelen, K., \& Busemeyer, M. (20O8). From collectivism towards segmentalism: Institutional change in German vocational training, MPIFG discussion paper 08/13, Coln, Max-Planck-institute.

Thelen, K., \& Busemeyer, M. (2011). Institutional change in German vocational training: from collectivism towards segmentalism, In: M. Busemeyer, C. Trampusch (Eds). The political economy of collective skill formation, (68-100). Oxford: Oxford University Press.

Wheelahan, L. (2016). 'College for all' in Anglophone countries - meritocracy or social inequality? An Australian example, Research in Post-Compulsory Education, 21:12, 33-48, doi:10.1080/13596748.2015.1125675

Wilkinson, R., \& Pickett, K. (2010). The Spirit Level: Why Equality is Better for Everyone. Harmondsworth: Penguin.

Winch, C. (2012). Dimensions of Expertise. London: Continuum.

\section{Biographical Notes}

James Avis is professor of Post-Compulsory Education and Training at the University of Huddersfield. His research interests lie in post-compulsory education, VET and life-long learning. He has written extensively on the policy contextualisation of postcompulsory education and VET, having addressed curriculum issues, methodological questions, teacher professionalism, as well as the lived experience of teachers and learners. He has a keen interest in the political economy of this sector and its policy contextualisation. Recent books include Issues in Post-Compulsory Education and Training; Education, Policy and Social Justice: Learning and Skills; Teaching in Lifelong Learning: a guide to theory and practice. 